\title{
Mellan verklighet och vision - en diskursanalys av Riktlinjer för Svenska kyrkans konfirmandarbete
}

\author{
Av Caroline Gustavsson
}

\begin{abstract}
In the Lutheran Church of Sweden, Guidelines for the Confirmation Work serves as a framework for the confirmation process and presents the conditions within which Swedish church congregations can conduct high-quality confirmation work. The latest version of the document was presented in 2008; the previous version was released in 2000 and the version before that was published in the late 1990s. The present article aims to contribute to a perspective on the 2008 edition by exploring the discourses that are reflected in the document. The analysis reveals three dominant Orders of discourse: the target group, the context, and the content. The results raise the question of how guidelines can be expected to balance the expectations and visions from the national church, the dioceses, and the congregations.
\end{abstract}

Keywords: church confirmation, guidelines, discourse analysis, Swedish church

CARoline Gustavsson (f. 1975). Lektor i religionspedagogik vid Teologiska Högskolan Stockholm, Akeshovsvägen 29, 16839 Bromma. E-post: caroline.gustavsson@ths.se

\section{INTRODUKTION}

Förutsättningarna för att bedriva konfirmandarbete har i en svensk kontext förändrats. På ett övergripande plan kan förändringarna beskrivas som en följd av en idag förändrad religiös socialisation.

Redan för tio år sedan kunde de flesta unga, som församlingarna i Svenska kyrkan mötte, beskrivas vara "nya" inför hur Svenska kyrkan uttrycker vad religiös tro är och vad ett religiöst engagemang handlar om (Lövheim \& Sjöborg 2006). De unga möter idag inte självklart uttryck för tro vare sig hemma eller i skolan. En av orsakerna till denna förändring är att skolans undervisning sedan 50-talet gått "från kunskap i religion till kunskap om religion" (Sjöborg \& Lövheim 2009:132). Allt sedan dess har ämnet önskat anta en tydligare objektiv och pluralistisk profil och 1969 ändrades ämnesbenämningen från kristendomskunskap till religionskunskap (Osbeck \& Skeie 2014; Kittelman Flensner 2015). Allt färre föräldrar pratar därtill om sin egen tro med sina barn och kan sägas dela föreställningen att tro ska komma inifrån och inte påtvingas barnet (Ahlin 2005:72).

Samtidigt möter unga människor religion på andra sätt än tidigare generationer, som en del av det multietniska och flerreligiösa samhället, i informella lärprocesser med kamrater och via olika medier (von Brömssen 2003; Lövheim 2004, 2012; Risenfors 2011; Gustavsson 2013). Kunskapen $i$ religion kan därför idag förväntas ta gestalt också i skolan men på andra sätt än genom den traditionella 
undervisningen. Det senare innebär dock ett inte självklart möte med Luthersk tradition.

Samtidigt som engagemanget i traditionell institutionell religiositet minskar finns exempel på att engagemanget $\mathrm{i}$ andra aktiviteter med "vagare religiös anknytning" ökar (Frisk \& Åkerbäck 2013:10; Voas 2010; Mason 2010). Exempel på det senare är besök hos helare, hälsomässor och friskvårdsaktiviteter.

Under åren har antalet konfirmander i Svenska kyrkan minskat. Svenska kyrkans statistikdatabas visar att antalet konfirmerade i procent av alla 15-åringar år 2015 var 27,8 \%. Denna siffra kan jämföras med 1970 då siffran var 80,7 \% (Döpta, konfirmerade 2016). Samtidigt går det att se exempel på den betydelse konfirmandtiden kan ha för yngre människors fortsatta engagemang $i$, och relation till, församlingarna. Jonas Bromander menar att konfirmandtiden är den kanske "enskilt viktigaste faktorn för människor att bygga relation med Svenska kyrkan" (Bromander 2012:5). Konfirmandarbetet har också beskrivits som "ett nyckelarbete för [Svenska kyrkans] framtid" (Riktlinjer 2000:5).

I detta sammanhang är det intressant att undersöka de riktlinjer som Svenska kyrkan har tagit fram för konfirmandarbetet. I Svenska kyrkan ska Riktlinjer för Svenska kyrkans konfirmandarbete ange "rambestämmelser för konfirmandarbetet" samt beskriva "förutsättningarna för att Svenska kyrkans församlingar ska kunna bedriva ett konfirmandarbete med hög kvalitet" (Riktlinjer 2008:37). ${ }^{1}$

I sin senaste version gavs Riktlinjerna ut 2008. Riktlinjerna som föregick denna utgåva kom 2000 och dokumentet dessförinnan i slutet av 1990-talet. Det kan med detta tidsintervall förväntas vara tid för en revidering och därför en lämplig tidpunkt för att aktualisera en diskussion kring Riktlinjernas såväl form som innehåll.

Studien som artikeln redovisar finner sin hemvisst inom pedagogik i en förståelse för pedagogik som "studiet av lärande och påverkansprocesser, och inte minst om villkoren för sådana processer, med utgångspunkt från den lärande människan och hennes livsvillkor, både som enskild individ och som medlem i en kollektiv gemenskap" (Qvarsell 2000:130). Studiens syfte är att utforska de villkor som Riktlinjerna utgör för arbetet med konfirmander i Svenska kyrkan. Villkor som i sin tur är av betydelse för frågor kring "förvärvandet av kunskaper, värderingar och handlingsmönster av religiös och livsåskådningsmässig art" (Larsson 2009:25). Det senare uttrycker att studien därför också kan betraktas som en studie inom det religionspedagogiska forskningsfältet.

Tidigare studier inom forskningsfältet har framförallt fokuserat konfirmandernas upplevelser av konfirmandtiden (se bland andra Lövheim \& Sjöborg 2006; Porath Sjöö 2008; Bromander 2012) men det finns också exempel på studier som ur ett läroplansperspektiv studerat texter som den Riktlinjerna ger exempel på (Innanen 2010).

I artikeln presenteras resultaten av en genomförd diskursanalys och relaterar inom ramen för denna text inte explicit till, eller diskuterar med, de nämnda studierna. Resultaten diskuteras här enbart i 
termer av utmaningar och möjligheter mot bakgrund av de potentiella konflikter som diskurs-analysen synliggör och önskar på det sättet få utgöra underlag för en fortsatt reflektion kring Riktinjernas betydelse som "villkor" i termer av såväl form som innehåll.

\section{Metod}

Studiens diskursanalytiska metod har inspirerats av Norman Fairclough och den tredimensionella modell han skriver fram i talet om text, diskursiv- och social praktik (Fairclough 1992, 1995).

I studien har dominerande diskurser analyserats utifrån förståelsen att en diskurs anger "ett bestämt sätt att tala om och förstå världen" (Winther Jörgensen \& Phillips 1999:7). En diskurs handlar om "språk och meningsutbyte" och anger ett slags ram för vad som sägs och inte sägs (Larsen 2009:102).

Analysen av den sociala praktiken handlar i enlighet med Fairclough om "the context of situation, the institutional context, and the wider societal context or 'context of culture"' (Fairclough 1995:95). En analys av den sociala praktiken synliggör vilket nät av diskurser som materialet ger exempel på samt hur de står i relation till varandra. Det ger därför utrymme för ett slags maktanalys. Analysen av den sociala praktiken är i studien mindre omfattande och aktualiserar här framförallt frågan om textens "vi".

Textanalys utgör en "form-and-meaning analysis" (Fairclough 1995:94). Med fokus på text har i studien prövats vad det råder strid om i texten, vad som tas för givet och vad som möjligen inte alls kommer till uttryck. Avseende det senare har framförallt det dokument som föregick Riktlinjerna varit av betydelse som ett jämförande exempel (Riktlinjer 2000). Textanalysen har skett i ett flertal steg. Dokumentet har till en början lästs förutsättningslöst med ett därefter allt tydligare fokus på de diskurser som kommer till uttryck i texten. I ett nästa steg har diskursernas förhållande till varandra prövats samt huruvida de kan läsas som uttryck för en vilja att etablera sig i samma domän och vad som kan beskrivas vara exempel på en diskursordning. I analysen har tre dominerande diskursordningar kunnat ses. Diskursordningar "are viewed as domains of hegemony and hegemonic (ideological) struggle, within institutions such as education as well as within the wider social formation" (Fairclough 1995:28). En diskursordning betecknar med andra ord "två eller flera diskurser som alla försöker etablera sig i samma domän" (Winther Jörgensen \& Phillips 1999:64). De olika diskurserna inom samma diskursordning synliggör därför en potentiell konflikt och möjliggör ett resultat som kan bidra till en fortsatt reflektion kring Riktlinjernas såväl form som innehåll.

Den diskursiva praktiken beskriver, i enlighet med Fairclough, produktionen, distributionen och konsumtionen av text och kan sägas utgöra relationen mellan text och social praktik (Fairclough 1995:94f). Analysen av den diskursiva praktiken har skett genom litteraturstudier där tidigare och för dokumentet betydelsefulla texter har tagits fram. Analysen av den diskursiva praktiken synliggör vilka texter som har legat till grund för och/eller föregått Riktlinjer för Svenska kyrkans konfirmandarbete från 2008 samt hur texten producerats och vem som förväntas läsa den.

I artikeln presenteras analysen av den diskursiva praktiken först, för att på 
det sättet placera Riktlinjerna i ett historiskt sammanhang. Därefter presenteras resultatet av textanalysen och tre potentiella konflikter i termer av "Målgrupp", "Kontext" samt "Innehåll". En reflektion görs kring det nät av diskurser som studien ger exempel på och artikeln avslutas därefter med en diskussion kring svårigheten i en framskrivning av riktlinjer i allmänhet och Riktlinjerna för Svenska kyrkans konfirmandarbete i synnerhet som för tillbaka på den pedagogiskt relevanta frågan kring Riktlinjernas betydelse som ett slags villkor för konfirmandarbetet.

\section{RikTLINJERNA I ETT HISTORISKT PERSPEKTIV}

Riktlinjer för Svenska kyrkans konfirmandarbete är resultatet av en omarbetning av tidigare riktlinjer. De riktlinjer som föregick omarbetningen gavs ut 2000. Riktlinjerna (2000) utgjorde då en av fyra delar under den samlande beteckningen Grunddokument för Svenska kyrkans undervisning (2000). Vid sidan av Riktlinjer för Svenska kyrkans konfirmandarbete (2000) fanns i denna samling även Lärande och undervisning - grund för Svenska kyrkans pedagogiska arbete (2000), I dialog med barn - grund för Svenska kyrkans arbete bland barn 0-14 år (1999) samt När skola och kyrka möts - grund för Svenska kyrkans arbete med skolan (2001).

Utgångspunkten för en omarbetning togs i de direktiv som projektet Konfirmand i Svenska kyrkan (2004-2007) tagit fram (Riktlinjer 2008:37). Direktiven föreskrev att riktlinjerna ska: vara förenliga med kyrkoordningen, avspegla att konfirmandarbetet är en del av kyrkans hela dopuppföljningsansvar, bidra till att skapa förutsättningar för ett konfirmandarbete med hög kvalitet, utgöra ett redskap för församlingens bearbetning av konfirmationens teologi och pedagogik samt uppmärksamma konfirmandåldern (Riktlinjer 2008:37). I slutet av oktober 2007 beslöt Kyrkostyrelsen att fastställa Riktlinjerna.

Riktlinjerna har utarbetats av en arbetsgrupp på sex personer under ledning av Lena Olsson Fogelberg. Stiftens konfirmandkonsulenter och biskopsmötet har därtill medverkat under processen med synpunkter på textens innehåll och utformning. Några personer har bidragit med särskilda delar av texten där Riktlinjernas skrivningar avseende begreppet livstydning på dopets grund, konfirmander med funktionsnedsättning, unga konfirmandledare, samverkan med Metodistkyrkan i Sverige och Svenska Missionskyrkan samt samordning mellan riktlinjernas rambestämmelser och kyrkoordningen har kommit att stå i särskilt fokus. Vilka organisationer eller positioner i Svenska kyrkan som de olika medarbetarna representerar framgår inte av dokumentet. Riktlinjerna vänder sig till "alla som har någon form av ansvar i konfirmandarbetet - anställda, frivilliga, förtroendevalda, lägerarrangörer och de kyrkliga utbildningarna" (Dela liv 2008:7).

Som ett slags komplement till Riktlinjerna gav Svenska kyrkan samma år ut dokumentet Dela liv - inspiration och fördjupning $i$ konfirmandarbetet. Skriften vänder sig till konfirmandledarna och önskar "stimulera till gemensam reflektion i konfirmandarbetslaget samt inspirera till det goda samtalet både i arbetslaget och i konfirmandgruppen" (Dela liv 2008:7). Dela liv innehåller texter som reflekterar kring Riktlinjernas skrivningar samt texter för inspiration och fördjupning och har skrivits av olika medarbetare i Svenska kyrkan. I övrigt har dokumentet utarbe- 
tats av samma arbetsgrupp som tagit fram Riktlinjerna. Inom ramen för denna studie analyseras inte Dela liv.

I ett längre historiskt perspektiv är den förändrade religionsundervisningen i den Svenska skolan en orsak till att Svenska kyrkans utbildningsnämnd bildades 1969. Detta då kyrkan som en följd av denna förändring såg sig tvungen att tydliggöra sin syn på kyrkans utbildningsuppdrag (Gustavsson 2006:16). Karl-Erik Brattgårds bok Kyrkans dopundervisning (1970) har beskrivits som ett av "[de] viktigaste dokumenten" från denna tid (Larsson 2009:60). Andra böcker av betydelse för frågor om Svenska kyrkans undervisning har varit John Ronnås bok Med engagemang och saklighet (1970), Ottar Ottersen Fostran - undervisning (1970) samt Hjalmar Sundéns bok Barn och Religion (1978). I slutet av 1970-talet gav kyrkan ut Kyrkans utbildning, förutsättningar och principer (1978). Tio år senare kom Mål och innehåll i Svenska kyrkans barn- och familjearbete (1987) och 1990 publicerades Kyrkans utbildning, undervisning för alla (1990).

I samband med diskussioner kring relationen kyrka-stat har frågan om kyrkotillhörighet aktualiserats. Dopet har i ljuset av detta ställts i förgrunden för en diskussion kring undervisning i Svenska kyrkan och resulterat bland annat i dokumenten Dop $i$ församlingen (1990) samt Dop och dopuppföljning (1996).

Riktlinjerna kan med andra ord ses i ljuset av de, över tid, förändrade förutsättningarna att vara kyrka. De förändrade förutsättningarna har i sin tur förändrat innebörden i, och förståelsen för, såväl undervisning som konfirmandarbete.

Det dokument som nu föreligger beskrivs ange "rambestämmelser för konfirmandarbetet samt beskriv[a] förutsättningarna för att Svenska kyrkans församlingar ska kunna bedriva ett konfirmandarbete med hög kvalitet" (s.7). Dokumentet ska vara ett redskap för stiftets tillsyn och främjande av konfirmandarbetet (s.7) samt ge stöd att utforma och genomföra ett konfirmandarbete som upplevs meningsfullt av alla berörda (s.8).

I en analys av den diskursiva praktiken går det att i ett historiskt perspektiv se hur nya riktlinjer önskat svara mot en brist man kunnat se i de föregående dokumenten. I en jämförelse med Riktlinjerna från 2000 går det som exempel att se hur den där framskrivna utläggningen av konfirmandens förväntade psykologiska förutsättningar i den senaste versionen från 2008 har tonats ner. Istället har man tydligare valt att lyfta fram bland annat "unga konfirmandledare", "lägervistelsen" och "konfirmander med funktionsnedsättning" (s.20f).

Analysen visar också att nya riktlinjer i flera fall svarar på en brist eller förändring som kyrkan kunnat se i samhället. Exempel på det senare är att texterna allt sedan 1970-talet önskat svara mot förväntade konsekvenser av en i skolan förändrad religionsundervisning.

\section{Potentiella konflikter}

Genom den diskursiva läsningen av texten kan tre dominerande diskursordningar ses. Den första handlar om konfirmandarbetets målgrupp och avslöjar en potentiellt diskursiv konflikt mellan diskursen "ålderskategori 15 år" och diskursen "livslångt lärande". Den andra diskursiva ordningen handlar om kontexten och en potentiellt diskursiv konflikt mellan "tradition" och "förändring". Den tredje diskursordningen kan benämnas innehåll och en potentiell konflikt kan ses mellan diskurserna "teori" 
och "praktik". I det följande exemplifieras respektive diskurs inom de tre diskursordningarna och frågor kring en möjlig konflikt aktualiseras.

\section{Målgrupp: ålderskategori 15 år - livslångt lärande}

I Riktlinjerna beskrivs målgruppen för konfirmandarbetet dels genom ett fokus på ålderskategori 15 år och dels genom intentionen att möta människor i alla åldrar för ett livslångt lärande. Den ena diskursen behöver inte självklart utesluta den andra. Den diskursordning som målgruppen synliggör pekar dock på svårigheten att skriva fram ett lärandedokument för en specifik åldersgrupp utan att denna särskiljs, eller i värsta fall exkluderas, från det övergripande arbetet kring lärande och undervisning på såväl riks-, som stifts- och församlingsnivå.

I en jämförelse med Riktlinjerna från 2000 har diskursen ålderskategori 15 tonats ner något 2008. Samtidigt beskrivs åldrarna mellan 14-15, även i dokumentet från 2008, utmärka sig i några avseenden. Dokumentet talar om ett brytningsskede som präglas av "sökandet efter identitet och tillhörighet, relationsbyggande och begynnande övergång till vuxenlivet (s. 15), "ett brytningsskede" (s. 8) och en fas av identitetsutvecklingen som "för de flesta inträffar i åldern 14-15 år" (s. 19). Det som beskrivs vara utmärkande för ålderskategorin motiverar enligt dokumentet perioden som en lämplig tid för konfirmandläsning.

En annan och potentiellt kontrasterande diskurs till ålderskategori 15 år är diskursen livslångt lärande. I dokumentet blir denna diskurs synlig i termer av "det livslånga lärandet i församlingen" (s. 10) och genom den betydelse man ger utvecklin- gen av pedagogik för olika åldrar (s. 9). Anders Wejryd skriver också i Riktlinjernas förord att konfirmandarbetet ska "sättas in i sitt sammanhang, nämligen församlingens ansvar att erbjuda dopundervisning för olika åldrar" (s. 7).

Båda diskurserna är verksamma samtidigt vilket syns genom skrivningen att uppdraget att "döpa och lära" är särskilt viktigt bland "barn och unga" (s. 10) samtidigt som konfirmandarbetet på ett övergripande plan beskrivs ingå i detta uppdrag och utgöra en viktig del av "det livslånga lärandet i församlingen" (s. 10). Det livslånga lärandet ska ges ett utrymme samtidigt som det lärande som dopet initierar tydligt skrivs fram i relation till en avgränsad ålderskategori, runt 14-15 år.

Den potentiella konflikten ligger i svårigheten att uppnå ett i församlingarna integrerat och livslångt lärande samtidigt som konfirmandtiden förväntas utgöra en avgränsad period. Åldersbestämningen har tonats ner något 2008 i jämförelse med föregångaren där man kunde läsa att konfirmandtiden "skall ses som en avgränsad tid med en tydlig början och ett tydligt slut" (Riktlinjerna 2000:14). I dokumentet från 2008 skriver man istället att "[d]et nya med denna version är att konfirmandarbetet tydligt sätts i relation till församlingens totala undervisningsansvar" (s. 7). Det senare tyder möjligen på att dokumentets författare själva ser den potentiellt diskursiva konflikten.

Trots detta tydliggörande och en ambition att integrera konfirmandarbetet med det övriga barn och ungdomsarbetet (s. 10) går det inte att se några exempel i dokumentet kring hur arbetet innan och efter kan se ut. Istället konstaterar man att många innan konfirmationen har haft en 
"ytterst sporadisk kontakt med kyrkan och [att] antalet odöpta konfirmander ökar" (s. 12). I texten uttrycker man också att konfirmationen kanske inte längre bär som form, och man vill därför komplettera med andra mötesplatser (s. 10). Skrivningarna synliggör en medvetenhet om förändrade förutsättningar att vara kyrka i vår tid. Samtidigt aktualiserar analysen frågan om riktlinjer för en avgränsad åldersperiod är svaret på de utmaningar som de förändrade förutsättningarna ställer kyrkan inför.

Med avseende på det senare så finns det en risk att konfirmandtiden blir en händelse isolerad från församlingens övriga arbete. Samma risk går att se i relation till Svenska kyrkans körverksamhet men förmodligen också i relation till andra grupper såsom öppna förskolan och scouterna (Gustavsson 2016). Körsångare ger som exempel uttryck för att de samlas kring och känner sig delaktiga i aktiviteten sång och musik samtidigt som de inte självklart uttrycker denna känsla av delaktighet i relation till kyrkans gudstjänst eller övriga gemenskap (Gustavsson 2016:135-205).

Om kyrkan vill inbjuda barn och ungdomar till en delaktighet i församlingen måste förmodligen den gemensamma aktiviteten och visionen för lärande och undervisning formuleras mer åldersövergripande. I den dokumentsamling som utgjorde föregångaren till Riktlinjerna var dokumentet Lärande och Undervisning tänkt att fylla lite av den funktionen. Dokumentet skulle "markera det ansvar Svenska kyrkan har för lärande och undervisning" samt diskutera "förutsättningarna för lärande och undervisning i Svenska kyrkan" (Lärande och undervisning 2000:8). Samtidigt följdes detta dokument av tre dokument som framförallt synliggör det pedagogiska arbetet i relation till tydligt avgränsade åldersgrupper, där samtliga tillhör de lägre åldrarna genom sitt fokus på barn, konfirmander och skola (Gustavsson 2006:19).

Att Riktlinjerna beskriver den avgränsade åldersgruppen som en förutsättning för en "effektiv och ändamålsenlig samverkan" (s. 19) talar för att valet att fokusera 14-15 åringar är ett i flera avseenden pragmatiskt val. Ett val som riskerar att stå i konflikt med den samtidiga ambitionen om ett integrerat och livslångt lärande. Den betoning som görs av att se konfirmandarbetet "i relation till församlingens totala undervisningsansvar" (s. 7) talar för en medvetenhet om denna konflikt. En medvetenhet som bjuder ett stort ansvar på såväl riks- som stifts- och församlingsnivå då ett dokument av detta slag riskerar att i sig bidra till att konfirmationen framstår som en isolerad företeelse.

\section{Kontext: \\ tradition - förändring}

Den andra diskursiva ordningen kan beskrivas i termer av kontext, dvs sammanhanget runt det konfirmandarbete som bedrivs och en potentiellt diskursiv konflikt mellan tradition och förändring.

Dokumentet genomsyras framförallt av en medvetenhet om de förändrade förutsättningarna att vara kyrka i vår tid. Förändringarna beskrivs i termer av en "globaliserad värld med snabba förändringar" (s. 8). Som tidigare nämnts konstateras i dokumentet att många innan konfirmationen har haft en "ytterst sporadisk kontakt med kyrkan och antalet odöpta konfirmander ökar" och man konstaterar också att alla idag inte är kyrkotillhöriga (s. 12).

Konfirmationsseden beskrivs inte län- 
gre vara självklar (s. 7). Denna medvetenhet menar man gör att församlingarna behöver fungerande former för dopundervisning där barn och unga ges möjlighet att växa i sin tro. Man konstaterar vidare att människor har skilda förutsättningar och livssituationer (s.9) och att denna medvetenhet idag krävs för en reflektion kring arbetet och mötet med konfirmander (s. 12). Att församlingar idag också möter ungdomar som tillhör en annan religion än den kristna lyfts också fram som en förändring (s. 23).

Vid sidan av denna förändringsdiskurs lyfts i dokumentet fram en diskurs som kan benämnas tradition och synliggör en potentiellt diskursiv konflikt. En del av traditionen uttrycks genom det ansvar varje generation har att "ge vidare det evangelium som den tagit emot" (s. 9). Här kan man notera ordet "ge", ett ord som valts istället för exempelvis "förmedla". Ordvalet tyder, tillsammans med andra delar av materialet, på en önskan om att lämna en förmedlingspedagogisk ansats. Det ger med andra ord exempel på ett implicit pedagogiskt teoretiskt ställningstagande, något det finns anledning att återkomma till.

I Riktlinjerna från 2000 har man ett ganska långt stycke om konfirmationshistorien. I dokumentet från 2008 uppmuntrar man istället tydligare församlingarna att frigöra "schemalagd tid för gemensam bearbetning av de teologiska och pedagogiska grundfrågorna". I församlingarna förväntas frågan om "vad som menas med livstydning på dopets grund" behandlas (s. 20).

De kristna bibelberättelserna lyfts fram som mönster för att "stärka konfirmandens identitet som människa" (s. 15) och kan också ses som exempel på traditions- diskursen.

Den potentiella konflikten mellan tradition och förändring kan i en mening uppfattas vara löst genom den tydliga betoning man i dokumentet gör av konfirmandernas liv. Konfirmandernas liv ska bli "synliggjorda och deras språk och gestaltande uttryck tagna på allvar" i andakter och gudstjänster, något man menar bidrar till deras aktiva engagemang och delaktighet (s. 14). Konfirmandernas liv och frågor kan i den meningen uppfattas överbygga en diskrepans mellan tradition och förändring.

Samtidigt kan betoningen av konfirmandens liv i sig tolkas som uttryck för förändringsdiskursen, där en tydlig kontextmedvetenhet gör det nödvändigt att ställa konfirmanden i centrum. Det tycks $i$ det perspektivet finnas en risk att den potentiella konflikten mellan de två diskurserna utmanar kyrkan att framförallt finna ett utrymme för traditionen. Riktlinjerna överlämnar ansvaret till församlingarna att i stora delar benämna och gestalta denna tradition och i Riktlinjerna ges framförallt utrymme för vad man tolkar som vår tids förändrade förutsättningar och dess innebörder.

\section{Innehåll: teori - praktik}

Den tredje diskursordning som dokumentet ger exempel på handlar om innehåll i det konfirmandarbete som församlingarna förväntas svara för och synliggör en potentiell konflikt mellan teori och praktik. Teori avser i detta sammanhang den diskurs som synliggörs genom en i dokumentet framskriven teoretisk, teologisk och/eller pedagogisk, reflektion samt genom föreskrivningar i dokumentet av ett specifikt sätt att agera med grund i dessa teoretiska antaganden. Praktik avser den diskurs som 
synliggörs genom beskrivningar av, och en utgångspunkt i, hur mötet med konfirmanderna förväntas se ut i församlingarnas praktiska arbete.

Riktlinjerna uttrycker genomgående konfirmandarbetets centrala betydelse för Svenska kyrkan och det ansvar som församlingarna primärt förväntas bära (s. 20). Detta ger exempel på en teoretisk diskurs som föreskriver ett specifikt sätt att agera. Framskrivningen av konfirmationens betydelse som "en aktualisering av dopet, en förböns- och välsignelsehandling och en förnyad sändning att vara Guds medarbetare i världen" kan också läsas som exempel på den teoretiska diskursen (s. 11).

I andra delar av materialet uttrycks en tydligt praktisk diskurs. Exempel på detta är betoningen av att det praktiska arbetet ska bäras av både "kvinnor och män" i arbetslaget samt betydelsen av unga ledare och lägerdygn som en del av konfirmandarbetet (s. 20). Riktlinjerna beskriver i dessa exempel hur mötet med konfirmanderna förväntas se ut i församlingarnas praktiska arbete.

I flera fall glider dock Riktlinjerna något oklart mellan teoretiska ställningstaganden och skrivningar av hur mötet med konfirmanderna i församlingens praktiska arbete ska se ut. Riktlinjerna ger som exempel på detta ett stort utrymme för hur arbetet ska bedrivas och vad som brukar beskrivas i termer av "metod". I dokumentet lyfts som exempel på detta "mötet och samtalet" fram som särskilt viktiga för den pedagogik som "svarar mot tonåringens behov" (s. 18). Framskrivningen skulle kunna förväntas ge exempel på den praktiska diskursen. Det som dock bidrar till en oklarhet i Riktlinjerna beror på att de teoretiska antaganden som ligger till grund för de metoder som föreslås, endast går att utläsa implicit. Att grunden för de pedagogiska ställningstaganden som görs i Riktlinjerna inte tydligt redovisas och att texten därför framstår som allmängiltig, synliggör därför en potentiell konflikt mellan de två diskurserna. Medarbetarna förväntas så att säga tillämpa en metod vars teoretiska grund de inte kan ta ställning till och inte självklart delar. Denna potentiella konflikt väcker frågan vad riktlinjer, som ett slags villkor för konfirmandarbetet, egentligen kan förväntas uttala sig om.

Så kan exempelvis "samtalet" ses som uttryck för en implicit föreskriven "livsfrågepedagogik" inspirerad av Sven Hartman och/eller Bo Dahlin (Hartman 1986; Dahlin 2004). Detta kan jämföras med den skrivning som görs i Riktlinjerna från 2000 där "fakta, förståelse, färdighet och förtrogenhet" lyfts fram som på olika sätt betydelsefulla former av kunskap (Riktlinjer 2000:19). Det ena behöver på inget sätt utesluta det andra men kan genom de skrivningar som nu görs komma att skapa mindre utrymme för "fakta" och en förmedlingspedagogisk ansats i församlingarna. Är detta i sig ett syfte bör detta teoretiska ställningstagande skrivas fram och på det sättet göras prövbart för kyrkans medarbetare.

I Riktlinjerna syns också genomgående uttryck för en pedagogisk ansats som kan vara inspirerad av bland andra Thomas Groome (Groome 1980, 2011). Detta genom talet om betydelsen av att konfirmanderna ska få forma sina livsberättelser och synen på konfirmandtiden som ett tillfälle för den enskilda människans berättelse att möta den stora berättelsen, "Guds berättelse som den uttrycks i bibelns ord, gudstjänst och trosbekännelse" (s. 7;11;18).

Såväl livsfrågepedagogiken som 
Thomas Groomes modell bygger på tydliga ställningstaganden avseende grundsynsfrågorna. Att en potentiell konflikt kan ses mellan de två diskurserna beror därför också av, att samtidigt som dessa skrivningar och implicita teoretiska utgångspunkter görs, betonas betydelsen av att församlingarnas medarbetare tillsammans gör "medvetna och tydligt redovisade ställningstaganden avseende grundsynsfrågorna" (s. 12). Med andra ord ger man implicit exempel på tydliga teoretiska ställningstaganden samtidigt som man uppmuntrar församlingarna att själva formulera sig utifrån den praktik man står i.

Oberoende av hur man förhåller sig till de teoretiska ställningstagandena i sig, väcks frågor huruvida Riktlinjerna ska förväntas skriva fram en pedagogisk grundsyn samtidigt som dokumentet uppmuntrar församlingarna att utarbeta en "plan för lärande och undervisning som beskriver hur församlingen verkar som lärande och undervisande miljö" (s. 11). De många gånger implicita teoretiska ställningstaganden som görs i dokumentet presenteras som om de vore allmängiltiga samtidigt som församlingarna uppmuntras att själva bearbeta grundsynsfrågorna (s. 20) och skriva fram en handlingsplan (s. 12). Glidningen mellan en ambition att ge en teoretisk grund och samtidigt tydliga ambitioner att utforma det praktiska arbetet kan förväntas bidra till att dokumentet upplevs otydligt.

\section{ETT NÄT AV DISKURSER}

De redovisade diskurserna synliggör potentiella konflikter inom de tre diskursordningarna målgrupp, kontext samt innehåll. I en analys av Riktlinjerna kan en del av spänningen i materialet ses som en följd av att funktionen och betydelsen av riktlinjer i sig, inte är självklar.

Ordet "riktlinjer" finner sin motsvarighet bland ord som "normer; direktiv; regler; lagar; principer" (Stora synonymordboken 1979). I Riktlinjerna från 2000 skriver man att "riktlinjer" innebär att de "anger den inriktning som allt konfirmandarbete bland tonåringar i Svenska kyrkan bör ha, oavsett vilken modell man väljer för uppläggningen" (Riktlinjerna 2000:5). Här betonas en intention som kan förväntas gälla även $\mathrm{i}$ 2008 års utgåva, nämligen att ange en riktning mer än lag, en rekommendation snarare än regel. Samtidigt skrivs det fram att Riktlinjerna anger "rambestämmelser för konfirmandarbetet" och utgör "ett redskap för stiftets tillsyn och främjande av konfirmandarbetet" (s. 7).

Otydligheten kring Riktlinjernas funktion, som ett slags villkor för arbetet, bidrar till en potentiell intressekonflikt mellan de olika nivåerna i Svenska kyrkan, mellan rikskyrkan, stiften och församlingarna. Den diskursiva ordningen "innehåll" synliggör detta och väcker frågor kring huruvida rikskyrkan ska göra teoretiska ställningstaganden i relation till en praktik de inte själva delar. Samtidigt överlåter Riktlinjerna àt församlingarna att själva formulera vad det innebär att tyda sitt liv på dopets grund. Det senare en teologisk fråga där rikskyrkan tvärtom kunde förväntas formulera sig tydligare.

I en analys av den diskursiva ordningen jag här väljer att benämna målgrupp väcks därtill frågan vem som i Riktlinjerna utgör kyrkans "vi" och "dem". Som exempel beskrivs Svenska kyrkans unga utgöra "de ungas egen röst i församlingens barnoch ungdomsverksamhet" (s. 10). Svenska kyrkans unga beskrivs i termer av "de" som förväntas tala för och företräda "dem", 
barn och unga. Ingen av de två skrivs med andra ord självklart fram som Riktlinjernas "vi".

I relation till samtliga diskursiva praktiker som materialet ger exempel på framträder rikskyrkan som det tydligaste "vi-et". Ett "vi" som instruerar såväl stift som församlingar om hur de bör tänka och handla. En rikskyrka som därför riskerar att uppfattas mer som en kontrollinstans än som en aktör.

De olika diskurser som går att se i en analys av dokumentet ger sammanfattningsvis exempel på en otydlighet kring av vem, för vem och kring vad Riktlinjerna skrivs fram. Resultatet aktualiserar frågan hur de riktlinjer kan förväntas se ut som ska balansera mellan förväntningar och visioner från såväl rikskyrkan som stiften och församlingarna.

\section{Avslutande diskussion}

I en tid då konfirmationen inte längre är en självklar erfarenhet för den enskilde, är utmaningarna för Svenska kyrkan förmodligen större än den text som anger Riktlinjer för Svenska kyrkans konfirmandarbete. Samtidigt synliggör texten ett villkor och ett slags vision och kan ange en inte obetydlig och gemensam utgångspunkt för samtliga församlingar i ett arbete för, och med, de konfirmander man möter.

Artikeln har aktualiserat en diskussion kring Riktlinjernas såväl form som innehåll men avser inte att ge några fullständiga svar på, om än förslag till, hur en revidering kan se ut. De svaren bör istället bäras tydligare av församlingarna och de medarbetare som står mitt i konfirmandarbetet. Studiens syfte har istället varit att utforska de villkor som Riktlinjerna utgör för arbetet med konfirmander i Svenska kyrkan med förhoppningen att analysens resultat făr vara ett av flera bidrag till underlag för fortsatta samtal.

Studiens viktigaste resultat är att de potentiella konflikterna som går att se mellan olika diskurser i Riktlinjerna, synliggör en svårighet i framskrivningen av riktlinjerna i sig. Det är också den huvudpoäng som artikeln önskar göra, nämligen att en del av dokumentets otydlighet och därmed utmaning måste ses som en följd av de många olika "nivåer" som dokumentet (re)presenterar. Riktlinjerna skrivs, som exempel på de olika nivåerna, fram för stift och församlingar, det ger församlingarna mandat att själva skriva fram handlingsplaner samtidigt som dokumentet dikterar hur konfirmandarbetslaget ska se ut. De olika nivåerna går med andra ord att förstå i relation till såväl form som innehåll.

Som en svepande bild av de många olika nivåerna som Riktlinjerna ger exempel på, kan sägas att Riktlinjerna presenterar församlingens förväntade arbete utifrån den skrivning som görs i Kyrkoordningen (s. 13f), det ger exempel på en organisationsnivå och förväntan, genom talet om att handlingsplanens mål ska vara utvärderingsbara (s. 17) samt exempel på hur konfirmandarbetslaget ska se ut (s. 20). Dokumentet uppmanar därtill stiften att utveckla arbetet med konfirmander med "funktionsnedsättningar" (s. 21). I samma dokument konstaterar man att musiken är viktig i unga människors liv (s. 22) och betydelsen av att välkomna människor med annan kristen tradition eller annan religion (s. 23). Dokumentet ger därtill exempel på den teologi och det innehåll man önskar att konfirmandarbetet ska ha, den pedagogiska hållning man vill ska genomsyra arbetet, den metod församlingarna bör använda och 
hur liturgin ska gestaltas (s. 16). Samtidigt som åldersgruppen 14-15 år lyfts fram betonar dokumentet ambitionen att möta alla. Församlingarna förväntas erbjuda konfirmandundervisning också för dem som är yngre och äldre och skapa mötesplatser med de ungdomar som inte deltar i konfirmandundervisningen (s. 13). Dokumentet vill ge stöd att "utforma och genomföra ett konfirmandarbete som upplevs som meningsfullt av alla berörda" (s. 8).

Riktlinjerna för Svenska kyrkans konfirmandarbete riskerar med den skrivning som idag görs att rikta sig till alla och ingen och bli en black om foten för alla de församlingar som förväntas gestalta den praktik som dokumentet föreskriver.

En reflektion som analysen av Riktlinjerna väcker är att dokumentet i sig uttrycker en ambition att motivera konfirmandarbetets plats i församlingarna. En motivering som tyder på att konfirmandarbetet inte delas av, eller självklart upplevs centralt för, alla medarbetare. Till exempel blir detta synligt i framskrivningen av hur arbetslaget ska se ut, där betydelsen tydliggörs av att "ledarskap, förhållningssätt och pedagogiska metoder" utformas "så att de bärs gemensamt i arbetslaget" (s. 20). Den betoning som görs av att få "alla med" är i sig intressant med tanke på hur Riktlinjerna skriver fram konfirmandarbetet som centralt för kyrkans inbjudan till ett livslångt lärande på dopets grund. Ett livslångt lärande på dopets grund skulle kunna förväntas utgöra en självklar aspekt av Luthersk tradition. En fråga, för inte minst de kyrkliga profilutbildningarna och rekryteringsansvariga, blir i det perspektivet, hur ett livslångt lärande motiveras av medarbetare som inte ger en självklar plats för konfirmandarbetet. Kan man anställas i
Svenska kyrkans församlingar för att arbeta för och med ett livslångt lärande på dopets grund om man inte ger konfirmandarbetet en självklar plats?

En möjlig modell för framskrivning av Riktlinjerna är i framtiden att stanna vid en enbart teoretisk nivå och låta ett kompletterande dokument i likhet med Dela liv (2008) ge exempel på hur arbetet kan genomföras i praktiken. I det fallet skulle en såväl teologisk som pedagogisk grundsyn tydligare skrivas fram och genom det kompletterande dokumentet gå i dialog med praktiken och frågor kring genomförbarheten i konkreta församlingar. Ett andra och möjligt alternativ är att Riktlinjerna enbart blir en sammanställning av de lagar som församlingarna genom Kyrkoordningen har att förhålla sig till samt direktiv kring organisatoriska frågor och ansvarsfördelning.

Oavsett hur framtida riktlinjer formuleras pekar studiens resultat på att de utgångspunkter Riktlinjerna tar, måste synliggöras tydligare. Det är därtill av stor betydelse att de personer som kommer att utgöra referensgruppen också presenteras utifrån sin profession och befattning $\mathrm{i}$ Svenska kyrkan. Det senare då de kan förväntas vara av stor betydelse för de diskurser som gör sig gällande i framtida texter.

\section{LiTTERATUR}

Ahlin, Lars. 2005. Pilgrim, turist eller flykting? En studie av individuell religiös rörlighet $i$ senmoderniteten. Stockholm: Symposium.

Brattgård, Karl-Erik. 1970. Kyrkans dopundervisning. Stockholm: Verbum.

Bromander, Jonas. 2012. En tid fylld av mening. En studie av konfirmandtiden som meningsbärande bland dagens unga. Uppsala: Svenska kyrkan.

von Brömssen, Kerstin. 2003. Tolkningar, för- 
handlingar och tystnader: elevers tal om religion i det mångkulturella och postkoloniala rummet. Göteborg: Acta Universitatis Gothoburgensis.

Dahlin, Bo. 2004. Om undran inför livet: barn och livsfrågor $i$ ett mångkulturellt samhälle. Lund: Studentlitteratur.

Dela liv. Inspiration och fördjupning $i$ konfirmandarbetet. 2008. Stockholm: Verbum förlag.

"Dop i församlingen: om att stärka dopets ställning" i Mitt $i$ församlingen 1992:10. Stockholm: Svenska kyrkans församlingsnämnd.

"Dop och dopuppföljning" i Mitt i församlingen 1995:8. Uppsala: Svenska kyrkans församlingsnämnd.

Döpta, konfirmerade, vigda och begravda enligt Svenska kyrkans ordning år 1970-2015. 2016. www.svenskakyrkan.se/statistik/ hämtad: 20160527.

Fairclough, Norman. 1992. Discourse and Social Change. Cambridge: Polity Press.

Fairclough, Norman. 1995. Critical Discourse Analysis. The Critical Study of Language. London: Longman.

Frisk, Liselotte \& Åkerbäck, Peter. 2013. Den mediterande dalahästen. Stockholm: Dialogos.

Groome, Thomas. 1980. Christian Religious Education. Sharing our Story and Vision. San Francisco: Harper \& Row.

Groome, Thomas. 2011. Will there be faith? A new vision for educating and growing disciples. New York: HarperOne.

Grunddokument för Svenska kyrkans undervisning. 2000. Uppsala: Svenska kyrkans nämnd för kyrkolivets utveckling.

Gustavsson, Caroline. 2006. $\AA$ andra sidan. En kritisk diskursanalys av Grunddokument för Svenska kyrkans undervisning. Magisteruppsats 10p. Lund: Pedagogiska instituti- onen.

Gustavsson, Caroline. 2013. Existentiella konfigurationer. Om hur förståelsen av livet tar gestalt $i$ ett socialt sammanhang. Stockholm: Stockholms universitet.

Gustavsson, Caroline. 2016. Delaktighetens kris. Gudstjänstens pedagogiska utmaning. Skellefteå: Artos.

Hartman, Sven. 1986. Barns tankar om livet. Stockholm: Natur \& Kultur.

I dialog med barn - grund för Svenska kyrkans arbete bland barn o-14 år. 1999. Uppsala: Svenska kyrkans nämnd för kyrkolivets utveckling.

Innanen, Tapani. 2010. "Bortglömd i en låda? Konfirmandplanernas betydelse for konfirmandmedarbetare" i: Berndt, Krupka \& Ingrid, Reite. 2010. Mellom pietisme og pluralitet. Konfirmasjonsarbeid $i$ fire nordiske land $i$ et empiriskt perspektiv. Oslo: IKOForlaget, s. 48-71.

Kittelman Flensner, Karin. 2015. Religious Education in Contemporary Pluralistic Sweden. Göteborg: Göteborgs universitet.

Kyrkans utbildning, förutsättningar och principer. 1978. Svenska kyrkans utbildningsnämnd. Stockholm: Verbum.

Kyrkans utbildning, undervisning för alla. 1990. Uppsala: Svenska kyrkan.

Larsen, Ann Kristin. 2009. Metod helt enkelt. En introduktion till samhällsvetenskaplig metod. Malmö: Gleerups.

Larsson, Rune. 2009. "Från kateketik till församlingspedagogik. Utvecklingslinjer i Svenska kyrkans undervisning under 1900talet" i Hanna Zipernovszky \& Caroline Gustavsson (red.) Religionspedagogiska reflektioner - skriven av och för Rune Larsson inför hans 75-års dag. Umeå: Zipernovszky, s. 55-73.

Larsson, Rune. 2009. "Reflektioner kring reli- 
gionspedagogikens identitet" i Hanna Zipernovszky \& Caroline Gustavsson (red.) Religionspedagogiska reflektioner - skriven av och för Rune Larsson inför hans 75-års dag. Umeå: Zipernovszky, s. 25-32.

Lärande och undervisning - grund för Svenska kyrkans pedagogiska arbete. 2000. Uppsala: Svenska kyrkans nämnd för kyrkolivets utveckling.

Lövheim, Mia. 2004. Intersecting Identities: Young people, Religion, and Interaction on the Internet. Uppsala: Teologiska institutionen.

Lövheim, Mia. 2012. "Religious Socialization in a Media Age" in Nordic Journal of Religion and Society (2012) 25 (2), s. 151-168.

Lövheim, Mia \& Sjöborg, Anders. 2006. Varför kyrkan? Ungas röster $i$ Stockholms stift. Stockholm: Diakonivetenskapliga institutets skriftserie 14 .

Mason, Michael. 2010. "The Spirituality of Young Australians" in Sylvia Collins-Maya \& Pink Dandelion (eds.) Religion and Youth. London: Ashgate, s. 55-62.

Mål och innehåll $i$ svenska kyrkans barn- och familjearbete. 1987. Stockholm: Verbum.

När skola och kyrka möts - grund för Svenska kyrkans arbete med skolan. 2001. Uppsala: Svenska kyrkans nämnd för kyrkolivets utveckling.

Osbeck, Christina \& Skeie, Geir. 2014. "Religious Education at Schools in Sweden" in Martin Rothgangel, Geir Skeie \& Martin Jäggle (eds.) Religious education at schools in Europe. Göttingen: V \& R Unipress, p. 237-266.

Ottersen, Ottar. 1970. Fostran - undervisning: en studiebok om riktlinjer för kyrkans pedagogiska verksamhet. Stockholm: Verbum.

Porath Sjöö, Elisabeth. 2008. Konfirmandernas bildningsresa: ungdomars berättelser om sitt deltagande $i$ konfirmandundervisningen. Lund: Lunds universitet, Pedagogiska institutionen.

Qvarsell, Birgitta. 2000. "Om samverkan som möjlighet och svårighet i pedagogisk fältforskning - forska i, om eller med omvärlden?" i Birgitta, Qvarsell (red.) Pedagogik i omvärld. FOLK-projektet, rapport nr 7. Stockholm: Pedagogiska institutionen, Stockholms Universitet.

Riktlinjer för Svenska kyrkans konfirmandarbete. 1978. Svenska kyrkans centralråd för evangelisation och församlingsarbete. Stockholm: Verbum.

Riktlinjer för Svenska kyrkans konfirmandarbete. 2000. Uppsala: Svenska kyrkans nämnd för kyrkolivets utveckling.

Riktlinjer för Svenska kyrkans konfirmandarbete. 2008. Stockholm: Verbum.

Risenfors, Signild. 2011. Gymnasieungdomars livstolkande. Göteborg: Göteborgs Universitet.

Ronnås, John \& Svärd, Stig (red.). 1970. Med engagemang och saklighet: en bok om religionsundervisning i skolan och trossamfunden. Stockholm: Moderna läsare, Frikyrkliga studieförbundet.

Sjöborg, Anders \& Lövheim, Mia. 2009. "Unga och religion" i Simon Lindgren (red.) Ungdomskulturer. Malmö: Gleerups.

Stora Synonymordboken. 1979. Stockholm: Strömberg förlag.

Sundén, Hjalmar. 1974. Barn och religion. Stockholm: Verbum.

Winther Jörgensen, Marianne \& Phillips, Louise. 2000. Diskursanalys som teori och metod. Lund: Studentlitteratur.

Voas, David. 2010. "Explaining Change over Time in Religious Involvement" in Sylvia Collins-Maya \& Pink Dandelion (eds.) Religion and Youth. London: Ashgate, s. 25-32. 